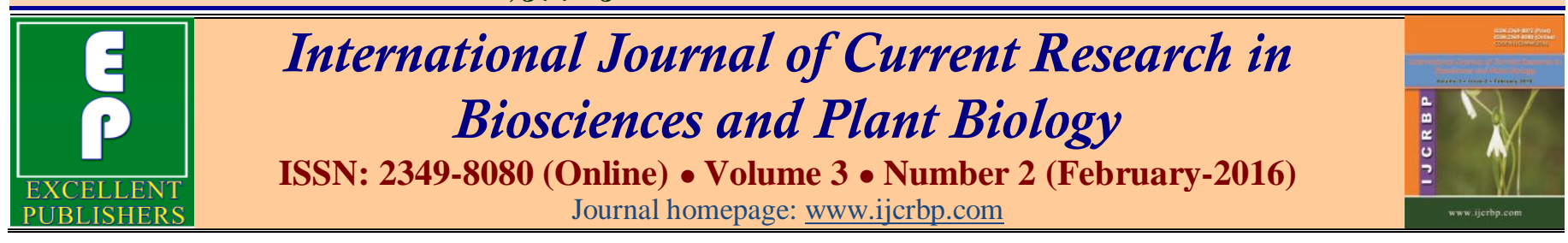

\title{
Cloning and Characterization of NPR1 Gene from Arabidopsis thaliana ecotype Col-0
}

\author{
Bipinchandra B. Kalbande* and Anita S. Patil \\ Department of Biotechnology, S.G.B. Amravati University, Amravati, Maharashtra, 444602, India \\ *Corresponding author.
}

\section{Abstract}

In the world of plants the non-expresser of pathogenesis-related gene $1(N P R I)$ is a key regulator of salicylic acid (SA) mediated systemic acquired resistance (SAR). It also plays an important role in the Jasmonic acid (JA) induced systemic resistance (ISR) signaling pathway and also arbitrates the crosstalk between SA-JA defense pathways to fine-tune defense responses of whole plant system. NPRI is one of the most agronomically important genes which are under extensive research for development of transgenic with broad spectrum disease resistance. In this study, we have isolated NPRI gene from genomic DNA of Arabidopsis thaliana ecotype Col-0. 2277 bp AtNPRI PCR product with single complete open reading frame has been cloned in pJET1.2 cloning vector and sequence characterized. AtNPRI encode a putative functional protein of 593 amino acids long. Sequence analysis in NCBI CDD domain reveals presence of important Ankyrin repeats domain and a BTB/POZ domain, found in some regulatory proteins and both of which mediate protein-protein interactions. Among the SARrelated gene with vast potential in disease resistance, AtNPRl is a leading candidate represents promising results in engineering resistance to broad-spectrum of pathogens.
\end{abstract}

\author{
Article Info \\ Accepted: 09 January 2016 \\ Available Online: 06 February 2016 \\ Keywords \\ Ankyrin repeats domain \\ Arabidopsis thaliana ecotype Col-0 \\ AtNPRI \\ $\mathrm{BTB} / \mathrm{POZ}$ domain \\ Induced Systemic Resistance (ISR) \\ Jasmonic acid (JA) \\ Salicylic acid (SA) \\ Systemic Acquired Resistance (SAR)
}

\section{Introduction}

With continuously changing climatic condition of the earth number of plant diseases are emerging stronger than ever and are tangible threat to worldwide agricultural production. Fungal, bacterial and viral diseases cause significant yield losses in most of the agricultural and horticultural species. Fungi cause more than $70 \%$ of all major crop diseases (Agrios, 2005; Sarah and Paul, 2005). Fungal diseases are rated either the most important or second most significant factor contributing to yield losses in crops like tomato (Lee and Raikel, 1995), wheat (Huang and Gill, 2001), barley (Smith, 2002), cotton (Cui et al., 2000), groundnut (Mace et al., 2006), grapevine (Dhekney et al., 2007) and others. In India, losses due to diseases have been estimated to be more than $10 \%$, accounting for an annual loss to the tune of Rs. 1200 million (Rangaswami and Mahadevan, 2005). In India, on an average $18 \%$ crop loss due to pests with a monetary loss of 90,000 $\mathrm{Cr}$ annually (CARE, 2009).

All high yielding verities are not mostly resistance enough to plant pathogens, as they should be. We have to use chemical pesticides and fungicides to control these diseases. Chemical control might be very effective for some diseases, but the effects are often non-specific. It kills beneficial organisms in the environment along with plant pathogens, and definitely they have undesirable health effects, safety and environmental risks (Manczinger et al., 2002). Pest and pathogens developing resistance to chemical pesticides is again a matter of great concern. Apart from chemical control, biological control measures have been used but with limited 
success. Deployments of resistant cultivars, selected or bred through conventional breeding are considered the most common and dependable method of controlling plant diseases. However, biotic loss to the tune of $42 \%$ occurs despite the use of all these conventional management practices. Alternative strategies including search for novel genes and their effective deployment through biotechnological approach would be a rapid and eco-friendly approach for controlling the crop diseases.

For biotechnologists, diseases control is a subject of great curiosity. Gene isolation and genetic transformation to develop transgenic resistance to diseases was the most noteworthy development in the area of varietal development for disease resistance. Improvements in genetic transformation technology allowed the genetic modification of almost all important food crops like rice, wheat, maize, mustard, pulses and fruits. Genetic engineering technology has proved to be beneficial in managing fungal (Lin et al., 2004; Wani, 2010, Parkhi et. al., 2010a and 2010b; Kumar et al., 2012), viral (Wani and Sanghera, 2010b) and bacterial (Jube and Borthakur, 2007; Sanghera et al., 2009) diseases in plants. Additionally, genetic engineering has the potential to increase disease tolerance to a range of pathogens, with no side effect on beneficial soil microbes (Liu et al., 2005).Genetic engineering of diseaseresistance through transfer of plant defense-related genes or pathogen-originated genes into crops is valuable in terms of cost, efficacy and reduction of pesticide usage (Shah et al., 1997; Salmeron and Vernooij, 1998; Rommens and Kishore, 2000; Stuiver and Custers, 2001).

A composite grid of defense responses have been evolved in plants associated with the response to local site of infection. Interaction between avirulence (avr) gene from pathogen and cognate resistance $(R)$ gene from plants are the key players in these responses (Heath, 2000; Durrant and Dong, 2004; Attaran et al., 2009; Mur et al., 2008). Further, in the process called as systemic acquired resistance (SAR), these defense responses are systemically induced in remote parts of the plants (Durrant and Dong, 2004; Dong, 2004; Mukhtar et al., 2009). Induction of the SAR pathway confers an increased, long-lasting, and broad-spectrum resistance to subsequent pathogen attacks for the whole plant (Ryals et al., 1996; Durrant and Dong, 2004; Mukhtar et al., 2009). Many research labs working on monocots and dicots established salicylic acid (SA) as a key player as a signaling molecule in SAR (Cao et al., 1994; Liu et al.,
2002; Fitzgerald et al., 2004; Vlot et al., 2008; Yuan et al., 2007; Chen et al., 2009; Makandar et al., 2006; Le et al., 2009). There is considerable amount of increase in SA levels both locally and systemically in plants, after the attack by pathogens (Malamy et al., 1990; Metraux et al., 1990; Rasmussen et al., 1991). In addition, SA is required for the induced expression of a set of pathogenesis-related (PR) genes (Cao et al., 1994; Gaffney et al., 1993; Rochon et al., 2006; Loake and Grant, 2007; Ward et al., 1991; Ryals et al., 1996).

NPR1 is a key regulator of SAR (Conrath et al., 2002; Kohler et al., 2002). Initial screening of Arabidopsis mutants that were insensitive to SA (or its chemical analogs, 2,6-dichloroisonicotic acid (INA) or benzothiadiazole $(\mathrm{BTH})$ ) reveled presence of NPRI gene(Cao et al., 1994; Shah et al., 1997; Delaney et al., 1995; Glazebrook et al., 1996; Ryals et al., 1997; Clarke et al., 1998). These screens identified a mutation designated as Non-Expressor of PR1 (NPRI). Further studies reveled that nprl mutants displayed reduced expression of PR genes upon SA treatment and were more susceptible to pathogens (Cao et al., 1994; Shah et al., 1997; Glazebrook et al., 1996; Ryals et al., 1997). Contrariwise, after over expression of NPRl gene, the transgenic plants exhibited increased resistance to pathogens, and were able to induce improved levels of PR genes in a dose-dependent fashion (Cao et al., 1998).

NPR1 expression is very low under normal circumstances. But, NPR1 gene expression level elevated by treatment of plants with SA, 2,6dichloroisonicotinic acid (INA) or benzo thiadiazole-7carbothioic acid S-methyl ester (BTH) (Heath MC, 2000; Durrant and Dong, 2004; Attaran et al., 2009; Cao et al.,1997; Ryals et al., 1997), and regulated through SA-induced WRKY DNA binding proteins (Yuet al., 2001) and redox changes (Mou et al.,2003). NPRl also plays an important role in the Jasmonic acid (JA)/Ethylene dependent Induced Systemic Resistance (ISR) signaling pathway and also mediates the crosstalk between SA-JA defense pathways to fine-tune defense responses (Feys and Parker 2000; Ndamukong et al., 2007; Spoel et al., 2003; Leon-Reyes et al., 2009; Koornneef and Pieterse, 2008). Biotrophic pathogens are controlled by SA-mediated defense pathway, while necrotrophic pathogens and herbivorous insects are countered by JA-mediated defense mechanism. NPRI mediates the antagonistic effect of SA on JA signaling by suppressing the expression of JA-responsive genes upon combined treatment of SA and Methyl Jasmonate (MeJA) (Spoel et al., 2003). 
Evidenced by several studies, it is well established fact that NPRI belongs to a multigene family in genome of plant kingdom, comprising up to six members in Arabidopsis, 5 in rice and 3 in banana (Chern et al., 2005; Yuan et al., 2007; Endah et al., 2008; Zhao et al., 2009). Similar pathways like that of the Arabidopsis NPRI (AtNPRl) mediated signaling pathway were also confirmed in rice (Chern et al., 2001). Additionally, homologs of AtNPRI have been cloned and characterized in numerous crop plants including cotton (Zhang et al., 2008), banana (Endah et al., 2008; Zhao et al., 2009), grapevine (Henanff et al., 2009), rice (Chern et al., 2005; Yuan et al., 2007), apple (Malnoy et al., 2007) and rosaceous tree (Pilotti et al., 2008). Over expression of AtNPRl in Arabidopsis (Cao et al., 1998), rice (Chern et al., 2001), tomato (Lin et al., 2004), wheat (Makandar et al., 2006) and apple (Malnoy et al., 2007) has been shown to boost fungal and bacterial resistance.

All these outcomes indicated that NPRI represents a creed of desirable candidate genes for genetic modifications in crop plants to improve disease resistance. There are reports of use of this AtNPRI gene from Col-0 ecotype in transgenic tomato which showed improved resistance to bacterial wilt (BW) and Fusarium wilt (FW), and modest degree of enhanced resistance to gray leaf spot (GLS) and bacterial spot (BS) (Lin et al., 2004). Keeping these results in mind we have also isolated this AtNPRlgene from Arabidopsis thaliana ecotype Col-0 for its further application in development of cotton transgenic for improved disease resistance.

\section{Materials and methods}

\section{Genomic DNA isolation}

Arabidopsis genomic DNA was extracted by CTAB buffer miniprep protocol method. $0.5 \mathrm{gm}$ of tissue sample (including leaf, stem and roots) was crushed and extracted in $800 \mu \mathrm{l}$ of Extraction Buffer $(100 \mathrm{mM}$ Tris$\mathrm{HCl} \mathrm{pH}$ 8, $20 \mathrm{mM}$ EDTA, $1.4 \mathrm{M} \mathrm{NaCl}, 2 \%$ CTAB, 2\% $\mathrm{PVP}$ and $0.5 \mathrm{M}$ glucose) in a two $\mathrm{ml}$ centrifuge tube. The mixture was vortexed for 45 secs and incubated at $65^{\circ} \mathrm{C}$ for $1 \mathrm{hr}$ with occasional shaking. Equal volume of chloroform : isoamyl alcohol (24:1) was added after incubation, mixed and centrifuged at $4{ }^{\circ} \mathrm{C}$ for $10 \mathrm{~min}$ at $12,000 \mathrm{rpm}$. The supernatant was removed carefully and put into the fresh two $\mathrm{ml}$ centrifuge tube. To this 0.8 volume of ice-cold isopropanol was added and mixed gently by inverting the tube for 5-6 times. This mixture was incubated at $-20^{\circ} \mathrm{C}$ for half an hour. Centrifuge the mixture at $12,000 \mathrm{rpm}$ at $4^{\circ} \mathrm{C}$ for $15 \mathrm{~min}$. Discard supernatant, let the DNA dry for two min and dissolve the DNA pellet in $500 \mu$ l of sterile double distilled water.

RNaseA treatment was given by adding RNaseA ( 20 $\mu \mathrm{g} / \mathrm{ml}$ final concentration) and incubating $37^{\circ} \mathrm{C}$ for half an hour. This treated DNA was re-precipitated by adding 0.1 volume of $3 \mathrm{M}$ sodium acetate $(\mathrm{pH}$ 5.2) and double volumes of ice cold ethanol. Mixture was incubated at $20^{\circ} \mathrm{C}$ for an hour. Precipitated DNA was collected by centrifugation at $12,000 \mathrm{rpm}$ at $4^{\circ} \mathrm{C}$ for $10 \mathrm{~min}$. Reprecipitated DNA was rinsed with $70 \%$ ethanol. Dry this DNA at room temperature for two minutes and redissolved in $200 \mu \mathrm{l}$ of sterile double distilled water. Check DNA concentration and purity by measuring the absorbance ratio A260/280. The quality of the DNA was further established by resolving $1 \mu \mathrm{DNA}$ on $0.8 \%$ agarose gel.

\section{Primer designing for AtNPR1 gene amplification}

Primers for amplification of complete functional gene were designed based on the Arabidopsis NPRI gene sequence available at National Centre for Biotechnology Information (NCBI) online. Forward primer (NPR1-F: 5'-CTTGGCTCTGCTCGTCAATGG-3') was designed 98 bp upstream from the start codon and reverse primer (NPR1-R: 5'-GGATGCAAAACGAAGAGCGA-3') was designed 95 bp downstream from stop codon so as to cover complete sequence.

\section{Amplification of full length AtNPR1 gene by touchdown PCR}

These primers were used to standardized PCR protocol for amplification of NPRl gene from Arabidopsis genomic DNA. Platinum $P f x$ DNA Polymerase (11708-013, Invitrogen, ThermoFisher Scientific, USA) was used for amplification. This is high fidelity and high endpoint Taq, with the proofreading $\left(3^{\prime} \rightarrow 5^{\prime}\right.$ exonuclease) activity with automatic hot-start effect. PCRx Enhancer Solution is included for higher primer specificity, broader magnesium concentration allowances, and broader annealing temperature parameters.

PCR cocktail for amplification of full length AtNPRI gene was made as detailed in Table1a. PCR protocol was standardized as mentioned in Table 2. Touchdown PCR technique was applied to increase specificity of the primers. In 45 cycle's repeats, primer annealing was started at $68^{\circ} \mathrm{C}$ in the first cycle and then one degree temperature was reduced per cycle, up to seven cycles to reach $60^{\circ} \mathrm{C}$ and from that point remaining 38 cycles were 
continued at $60^{\circ} \mathrm{C}$ primer annealing temperature. Negative controls were maintained to check non-specific amplification, if any. The amplified product was checked by resolving on $1.0 \%$ agarose gel and it was documented on gel documentation system (AlphaimagerTM 2200, USA).

Table 1a. PCR cocktail for Platinum $P f x$ DNA Polymerase.

\begin{tabular}{lll}
\hline Sr. No. & Components & Volume $(\mu \mathrm{l})$ \\
\hline 1 & $10 \mathrm{x}$ PCR amplification buffer & 10.0 \\
2 & $10 \mathrm{mM}$ dNTPs & 1.0 \\
3 & $10 \mathrm{mM} \mathrm{MgSO} 4$ & 1.0 \\
4 & NPR1-F $(10 \mathrm{mM})$ & 1.0 \\
5 & NPR1-R $(10 \mathrm{mM})$ & 1.0 \\
6 & DNA template $(50 \mathrm{ng} / \mu \mathrm{l})$ & 2.0 \\
7 & Platinum Pfx DNA Polymerase $(5 \mathrm{U} / \mu \mathrm{l})$ & 0.3 \\
8 & 10x PCR Enhancer solution & 5.0 \\
9 & Sterile double distilled water & 25.4 \\
& Total volume & 50.0 \\
\hline
\end{tabular}

* Whole reaction was set up in ice bath below $4^{\circ} \mathrm{C}$.

Table 1b. PCR cocktail for Genaxy Taq DNA Polymerase.

\begin{tabular}{lll}
\hline Sr. No. & Components & Volume $(\boldsymbol{\mu l})$ \\
\hline 1 & 10x PCR amplification buffer $\left(+\mathrm{MgCl}_{2}\right)$ & 2.5 \\
2 & 10x BSA & 0.5 \\
3 & $25 \mathrm{mM}$ dNTPs & 0.5 \\
4 & NPR1-F $(10 \mathrm{mM})$ & 0.5 \\
5 & NPR1-R $(10 \mathrm{mM})$ & 0.5 \\
6 & DNA template $(50 \mathrm{ng} / \mu \mathrm{l})$ & 2.0 \\
7 & Taq DNA Polymerase $(5 \mathrm{U} / \mu \mathrm{l})$ & 0.5 \\
8 & Sterile double distilled water & 18.0 \\
& Total volume & 25.0 \\
\hline
\end{tabular}

* Whole reaction was set up in ice bath below $4^{\circ} \mathrm{C}$.

Table 2. Details of touchdown PCR protocol optimized for transgenic event characterization.

\begin{tabular}{|c|c|c|c|c|c|c|c|c|c|c|c|}
\hline \multirow{2}{*}{$\begin{array}{l}\text { Primer } \\
\text { combination }\end{array}$} & \multicolumn{2}{|c|}{ Initial denaturation } & \multicolumn{2}{|c|}{ Denaturation } & \multicolumn{2}{|c|}{ Annealing } & \multicolumn{2}{|c|}{ Extension } & \multicolumn{2}{|c|}{ Final extension } & \multirow[b]{2}{*}{ Product size (bp) } \\
\hline & $\begin{array}{l}\text { Temp } \\
\left({ }^{\circ} \mathrm{C}\right)\end{array}$ & $\begin{array}{l}\text { Time } \\
(\mathrm{min})\end{array}$ & $\begin{array}{l}\text { Temp } \\
\left({ }^{\circ} \mathrm{C}\right)\end{array}$ & $\begin{array}{l}\text { Time } \\
(\mathrm{Sec})\end{array}$ & $\begin{array}{l}\text { Temp } \\
\left({ }^{\circ} \mathrm{C}\right)\end{array}$ & $\begin{array}{l}\text { Time } \\
(\mathrm{Sec})\end{array}$ & $\begin{array}{l}\text { Temp } \\
\left({ }^{\circ} \mathrm{C}\right)\end{array}$ & $\begin{array}{l}\text { Time } \\
(\mathrm{Sec})\end{array}$ & $\begin{array}{l}\text { Temp } \\
\left({ }^{\circ} \mathrm{C}\right)\end{array}$ & $\begin{array}{l}\text { Time } \\
(\min )\end{array}$ & \\
\hline NPR 1-F & 94 & 5 & 94 & 40 & $* 68-60$ & 30 & 72 & 180 & 72 & 5 & 2300 \\
\hline NPR1-R & \multicolumn{2}{|c|}{01 Cycle } & \multicolumn{6}{|c|}{45 Cycles } & \multicolumn{2}{|c|}{01 Cycle } & 2300 \\
\hline
\end{tabular}

* Touchdown PCR temperature, annealing temperature decrease from $68^{\circ} \mathrm{C}$ to $60^{\circ} \mathrm{C}$

\section{Gene cloning in PCR cloning vector}

Before proceeding for cloning, PCR product was purified with the help of PCR purification kit (12500-50, UltraClean ${ }^{\circledR}$ PCR Clean-Up Kit, Genaxy, USA). This purified AtNPRI amplicon was cloned in pJET1.2 cloning vector (CloneJET PCR Cloning Kit, \#K1231, Thermo Scientific, USA). The kit features the novel positive selection cloning vector pJET1.2/blunt. This vector contains a lethal gene which is disrupted by ligation of a DNA insert into the cloning site. As a result, only cells with recombinant plasmids are able to propagate, eliminating the need for expensive blue/white screening. Our PCR product was blunt end product and can be cloned directly into pJET1.2 vector. The ligation reaction was prepared as per Table 3 and the ligation mix was incubated at $22^{\circ} \mathrm{C}$ for $20 \mathrm{~min}$ for optimum performance. This ligation mix after incubation was directly used for transformation procedure.

For transformation E. coli XL1-Blue strain was used and the transformation was done by chemical transformation method. For this TransformAid Bacterial Transformation Kit (\#K2711, Thermo, USA) was used. From a fresh culture plate of XL1-Blue, overnight culture of single colony of $E$. coli in $2 \mathrm{ml} \mathrm{C}$-medium was start at $37^{\circ} \mathrm{C}$ in incubator shaker. Further treatment was done as per the manufacturer's protocol. At the end, $5 \mu 1$ fresh ligation 
mix was added in $200 \mu \mathrm{l}$ PCR tube and chilled on ice. To this chilled $5 \mu \mathrm{l}$ ligation mix, $50 \mu \mathrm{l}$ freshly prepared competent cells were added. Mixed by tapping and centrifuged shortly to collect mixture at bottom. The mixture was incubated on ice for $5 \mathrm{~min}$ and immediately plated on pre-warmed LB plate with ampicillin (final concentration of $75 \mu \mathrm{g} / \mathrm{ml}$ ). This seeded plate was incubated at $37^{\circ} \mathrm{C}$ overnight in incubator.

Table 3. DNA ligation reaction on ice.

\begin{tabular}{lllll}
\hline Sr. No. & Components & Volume $(\mu \mathrm{l})$ & Mixing & Incubation \\
\hline 1 & 2x Reaction buffer & 10.0 & & Incubate the \\
2 & Purified PCR product & 01.0 & Vortex briefly & ligation mixture at $22^{\circ} \mathrm{C}$ \\
3 & pJET1.2/blunt cloning vector $(50 \mathrm{ng} / \mu \mathrm{l})$ & 01.0 & and centrifuge for $3-5 \mathrm{~s}$ & for $20 \mathrm{~min}$. \\
4 & T4 DNA ligase & 01.0 & & \\
5 & Nuclease free sterile water & 07.0 & & \\
& Total volume & & & \\
\hline
\end{tabular}

*Use this cocktail directly for transformation.

\section{Analysis of recombinant clones}

Colonies appeared on plate the next day can be considered positive because of special selection strategy of vector. But we also confirmed the recombinant clones by single and double restriction digestion and PCR with gene specific primers. First grid plate was prepared on LB + ampicillin plate. While streaking the grid with sterilized tooth pick, start overnight culture in $2 \mathrm{ml} \mathrm{LB}+$ ampicillin broth with the same tooth pick. Make sure to annotate the grid plate and broth culture tubes properly. These tubes were incubated in incubator shaker at $37^{\circ} \mathrm{C}$ and 90rpm overnight. Next day, this fresh bacterial culture was used to isolate plasmid DNA. Plasmid isolation was done by the miniprep protocol described by Chakrabarty et al. (2010). Only first five colonies (pJET-AtNPR1-1 to pJETAtNPR1-5) were processed for analysis. Plasmid DNA was checked by resolving on $0.8 \%$ agarose gel and documented on gel documentation system (AlphaimagerTM 2200, USA).

BamHI single digestion cocktail consist of $3 \mu \mathrm{l}$ plasmid DNA, $2 \mu 1$ 10x BamHI buffer, $0.25 \mu \mathrm{l}$ of $10 \mathrm{U} / \mu \mathrm{l} \mathrm{BamHI}$ (Fermentas, USA) restriction enzyme and sterile double distilled water added up to $20 \mu 1$ (Table 4a). SalI single digestion cocktail consist of $3 \mu 1$ plasmid DNA, $2 \mu 110 \mathrm{x}$ buffer-O, $0.25 \mu 1$ of $10 \mathrm{U} / \mu \mathrm{l}$ SalI (Fermentas, USA) restriction enzyme and sterile double distilled water added up to $20 \mu \mathrm{l}$ (Table 4a). Double digestion cocktail consist of $3 \mu 1$ plasmid DNA, $2 \mu 1$ 10x BamHI buffer, $0.25 \mu 1$ of $10 \mathrm{U} / \mu \mathrm{l} \mathrm{BamHI}$ (Fermentas, USA) restriction enzyme, $0.25 \mu \mathrm{l}$ of $10 \mathrm{U} / \mu \mathrm{l}$ SalI (Fermentas, USA) restriction enzyme and sterile double distilled water added up to $20 \mu \mathrm{l}$ (Table $4 \mathrm{~b}$ ). Digestion cocktail were incubated at $37^{\circ} \mathrm{C}$ for two and a half hour. Digested plasmid DNA was checked by resolving on $1.2 \%$ agarose gel and documented on gel documentation system (AlphaimagerTM 2200, USA).
Positive clones were also confirmed by PCR amplification of the At-NPRl gene using gene specific primers, NPR1-F and NPR1-R. PCR cocktail was prepared as per Table 1b. Here, Taq DNA polymerase from Genaxy (USA) was used for amplification. The PCR protocol was followed as explained in Table2. PCR products were checked by resolving on $1.0 \%$ agarose gel and documented on gel documentation system (AlphaimagerTM 2200, USA).

\section{Gene Sequencing and characterization}

The positive recombinant clones pJET-At-NPRlin E. coli XL1-Blue were further cultured in $5 \mathrm{ml} \mathrm{LB} \mathrm{+}$ Ampicillin broth at $37^{\circ} \mathrm{C}$ overnight in incubator shaker. Negative control without any inoculum was kept to check any contamination in liquid broth itself. Next day, this overnight grown culture was used to isolate plasmid DNA with the help of AxyPrep Plasmid Miniprep Kit (AP-MN-P-50, Genaxy, USA). This plasmid DNA was then sent for sequencing to Xcelris Labs Ltd., Ahmedabad, India. The sequences obtained were put together using software DNA BASER Sequence Assembler4.10. This sequence was submitted in GenBank (KF564649). Alignment and base composition analysis of the nucleotide sequence of the AtNPRl gene was performed with the BLASTn (Gotea et al., 2003). Also amino acid sequence of AtNPRI protein was compared online using BLASTp software and conserved domains in the AtNPRI protein were identified using the National Center for Biotechnology Information (NCBI) Conserved Domains software (Marchler-Bauer et al., 2005) online. This AtNPRl sequence was compared with ArabidopsisNPR1 mRNA sequence (NM_105102) to get an idea about AtNPRImRNA sequence and amino acid sequence. 
Table 4a. Single digestion cocktail.

\begin{tabular}{llll}
\hline Sr. No. & Components & Volume $(\boldsymbol{\mu l})$ & Incubation \\
\hline 1 & 10x Buffer BamHI / Buffer O & 2.00 & \\
2 & BamHI or SalI enzyme $(10 \mathrm{U} / \mu \mathrm{l})$ & 0.25 & Incubate the mixture at $37^{\circ} \mathrm{C}$ \\
3 & Plasmid DNA & 2.00 & for two and a half hour \\
4 & Sterile double distilled water & 15.75 & 20.00 \\
& Total volume & & \\
\hline
\end{tabular}

* Whole reaction was set up in ice bath below $4{ }^{\circ} \mathrm{C}$.

Table 4b. Double digestion cocktail.

\begin{tabular}{llll}
\hline Sr. No. & Components & Volume $(\boldsymbol{\mu l})$ & Incubation \\
\hline 1 & 10x Buffer BamHI & 2.00 & \\
2 & BamHI enzyme $(10 \mathrm{U} / \mu \mathrm{l})$ & 0.25 & Incubate the mixture at $37^{\circ} \mathrm{C}$ for \\
3 & SalI enzyme $(10 \mathrm{U} / \mu \mathrm{l})$ & 0.25 & two and a half hour \\
4 & Plasmid DNA & 2.00 & 15.60 \\
5 & Sterile double distilled water & 20.00 & \\
\hline
\end{tabular}

* Whole reaction was set up in ice bath below $4{ }^{\circ} \mathrm{C}$.

\section{Results and discussion}

Quality genomic DNA of Arabidopsis thaliana was extracted in lab using CTAB buffer miniprep protocol (Fig. 1). Gene specific primers NPR1-F and NPR1-R were used in touchdown PCR with Platinum Taq have given expected amplicon of 2277 bp (Fig. 2). This blunt ended PCR product after purification cloned in pJET1.2 vector and the positive recombinant clones were confirmed by single digestion, double digestion and gene specific PCR. First five recombinant clones (pJETAtNPR1-1 to pJET-AtNPR1-5) were processed for plasmid DNA isolation by lab miniprep protocol (Chakrabarty et al., 2010) (Fig. 3a). Single digestion of these plasmids with enzyme BamHI and SalI simultaneously produced liner plasmid band of nearly 5.3 $\mathrm{kb}$ (Fig. 3b, 3c), which was expected, as the size of vector was $3 \mathrm{~kb}$ and PCR product was of $2277 \mathrm{bp}$. And hence, double digestion with enzyme BamHI and SalI have produced two bands, first was of $3 \mathrm{~kb}$ (cloning vector) and second was of approximately $2.3 \mathrm{~kb}$ (PCR product) (Fig. 3d). All these five plasmids were also tested with gene specific primers NPR1-F and NPR1-R, and produced PCR product of approximately $2.3 \mathrm{~kb}$ as expected (Fig. 3e). These tested positive clone plasmids were sequenced for gene of interest cloned in them.

The NPRI gene was isolated and cloned from Arabidopsis thaliana ecotype Col-0 that has one uninterrupted ORF. Assembled sequence is of $2277 \mathrm{bp}$ and from start codon to stop codon it is 2079 bp in length. Gene contains four coding regions i.e. 4 exons which are interrupted by 3 noncoding regions i.e. introns. First exon is of $561 \mathrm{bp}$, second exon is of $736 \mathrm{bp}$, third exon is of $204 \mathrm{bp}$ and fourth exon is of $281 \mathrm{bp}$. Combining all complete coding sequence i.e., mRNA sequence of AtNPRl is of 1782 bp (Fig. 4) which encode a putative protein of 593 amino acids (aa). The nucleotide sequence was submitted in GenBank (Accession no. KF564649). Protein information of AtNPR1 coding region is available in GenPet at NCBI (Accession no. AIK27558).

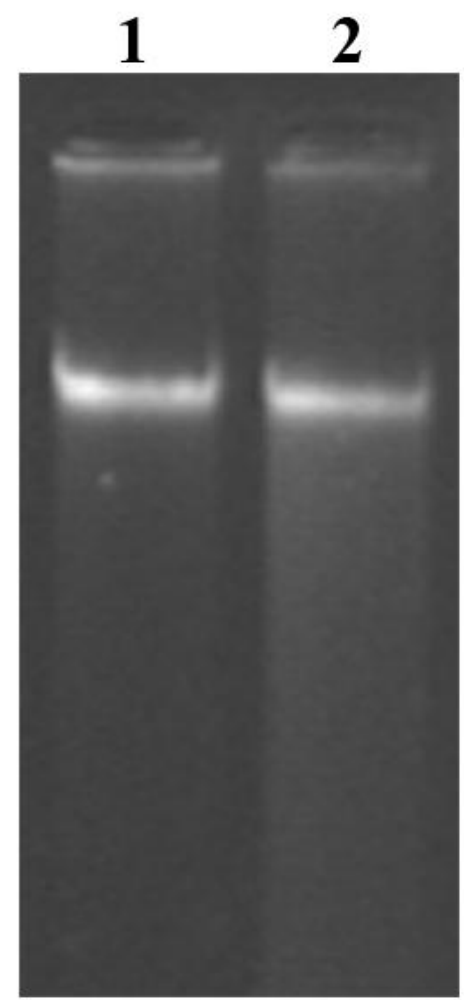

Fig. 1: Arabidopsis Genomic DNA ( $2 \mu \mathrm{l})$ separated on $0.8 \%$ agarose gel. Lane 1 and 2, genomic DNA ( $2 \mu \mathrm{l})$ samples. 


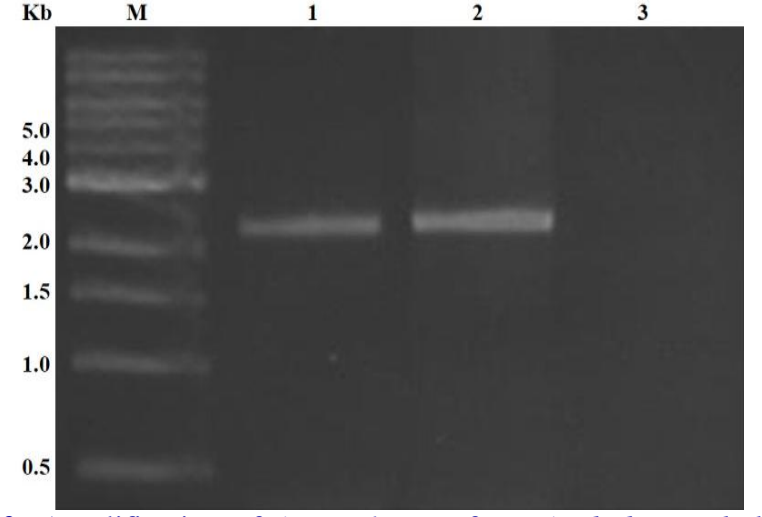

Fig. 2: Amplification of AtNPRl gene from Arabidopsis thaliana ecotype Col-0 using gene specific primers NPR1-F and NPR1-R. Lane M, 1 Kb DNA ladder, Lane 1 and 2, Arabidopsis samples, Lane 3, PCR negative.

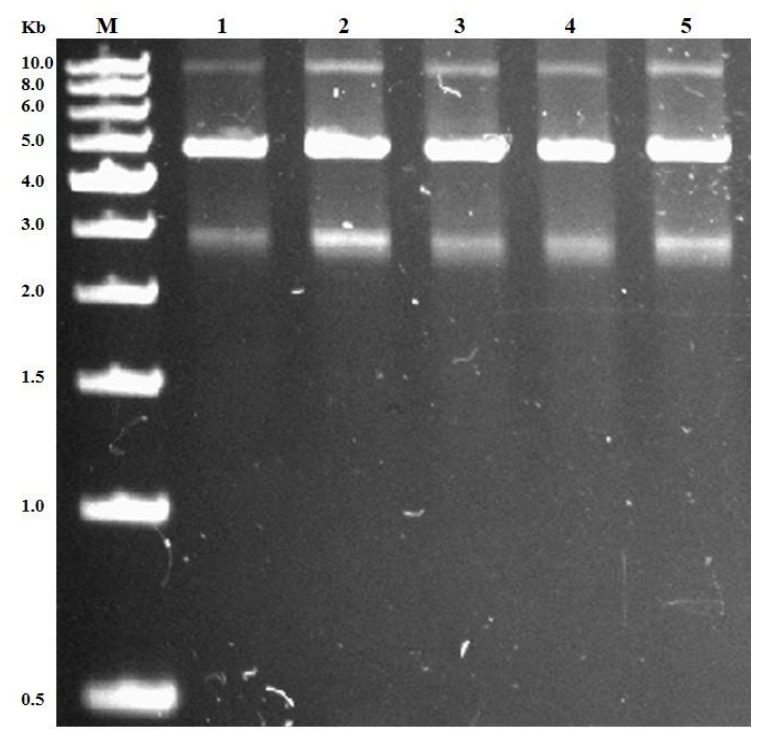

Fig. 3a: First five recombinant clones (pJET-AtNPR1-1 to pJETAtNPR1-5) plasmid ( $3 \mu \mathrm{l})$ separated on $0.8 \%$ agarose gel. Lane 1, pJET-AtNPR1-1; Lane 2, pJET-AtNPR1-2; Lane 3, pJET-AtNPR13; Lane 4, pJET-AtNPR1-4; Lane 5, pJET-AtNPR1-5.

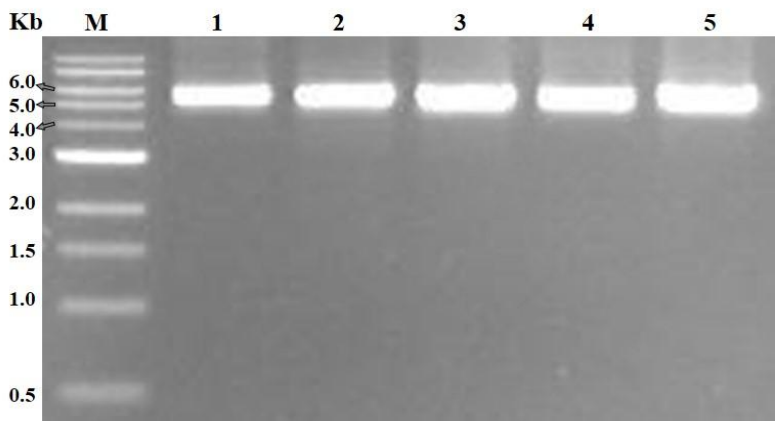

Fig. 3b: Single digestion with BamHI restriction enzyme. $3 \mu \mathrm{l}$ plasmid DNA from first five recombinant clones (pJET-AtNPR1-1 to pJET-AtNPR1-5) were subjected to single digestion to confirm AtNPRlgene integration. Digested product (5.3 Kb linear plasmid) was separated on $1.2 \%$ agarose gel. Lane M, $1 \mathrm{~Kb}$ DNA ladder. Lane 1, pJET-AtNPR1-1; Lane 2, pJET-AtNPR1-2; Lane 3, pJETAtNPR1-3; Lane 4, pJET-AtNPR1-4; Lane 5, pJET-AtNPR1-5.

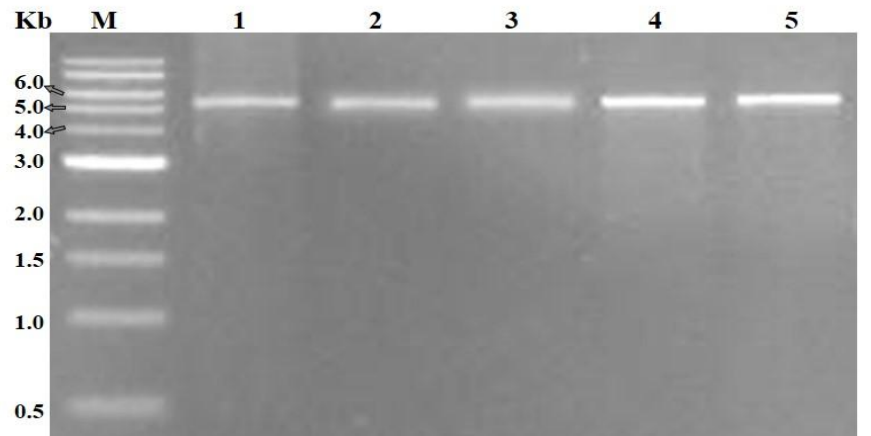

Fig. 3c: Single digestion with SalI restriction enzyme. $3 \mu$ plasmid DNA from first five recombinant clones (pJET-AtNPR1-1 to pJETAtNPR1-5) were subjected to single digestion to confirm AtNPRlgene integration. Digested product (5.3 Kb linear plasmid) was separated on $1.2 \%$ agarose gel. Lane $\mathrm{M}, 1 \mathrm{~Kb}$ DNA ladder. Lane 1, pJET-AtNPR1-1; Lane 2, pJET-AtNPR1-2; Lane 3, pJETAtNPR1-3; Lane 4, pJET-AtNPR1-4; Lane 5, pJET-AtNPR1-5.

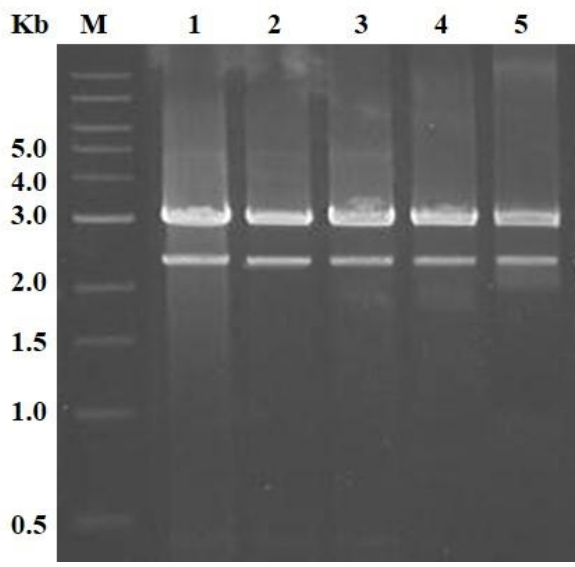

Fig. 3d: Double digestion with BamHI + SalI restriction enzyme. 3 $\mu \mathrm{l}$ plasmid DNA from first five recombinant clones (pJET-AtNPR11 to pJET-AtNPR1-5) were subjected to double digestion to confirm AtNPRlgene integration. Digested product $(3.0 \mathrm{~Kb}$ vector and $2.3 \mathrm{~Kb}$ PCR product) was separated on $1.2 \%$ agarose gel. Lane M, $1 \mathrm{~Kb}$ DNA ladder. Lane 1, pJET-AtNPR1-1; Lane 2, pJETAtNPR1-2; Lane 3, pJET-AtNPR1-3; Lane 4, pJET-AtNPR1-4; Lane 5, pJET-AtNPR1-5.

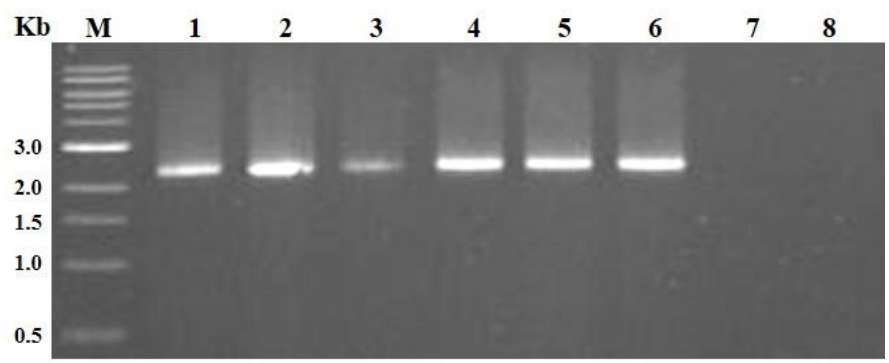

Fig. 3e: Gene specific PCR by NPR1-F and NPR1-R primers. Plasmid DNA from first five recombinant clones (pJET-AtNPR11 to pJET-AtNPR1-5) were subjected PCR detection to confirm AtNPRl gene integration. PCR product was separated on $1.0 \%$ agarose gel. Lane M, $1 \mathrm{~Kb}$ DNA ladder. Lane 1, pJET-AtNPR1-1; Lane 2, pJET-AtNPR1-2; Lane 3, pJET-AtNPR1-3; Lane 4, pJETAtNPR1-4; Lane 5, pJET-AtNPR1-5. 
Nucleotide BLAST search of GenBank revealed that AtNPRl shared the identity of $78 \%$ to $99 \%$ with Arabidopsis NPRlsequences available. Protein BLAST results showed highest homology with $100 \%$ amino acid identity to non-expressor of PR1 protein of Arabidopsis lyrata subsp. Lyrata (XP_002886354). The concise results of the conserved domains analysis of the deduced AtNPRI amino acid sequence using the NCBI CDD program indicated that it contains Ankyrin repeats (ANK) domains(ARD) (aa 271-369), NPR1/NIM1 like defense protein $\mathrm{C}$ terminal (aa 370-565), BTB zinc finger domain (for BR-C, ttk and bab) or POZ (for Pox virus and Zinc finger) domain (aa 66-192) and a domain of unknown function (aa 231-271) (Fig. 5). These are typical features of NPRI genes that are highly conserved across many species (Cao et al., 1997; Aravind and Koonin, 1999; Chern et al., 2005; Endah et al., 2008). Amino acids critical for the NPRI function as well-defined by genetic mutants, such as npr1-1 $(\mathrm{H})$ and npr1-2 (C) (Cao et al., 1997), and nim1- 4 (R) (Ryals et al., 1997), were also conserved. In the sequence there are conserved eight $\mathrm{Cys}$ residues which are possibly engaged in the oligomerization and the nuclear localization of NPRI or NPR1-like proteins (Mou et al., 2003; Yuan et al., 2007).

An evolutionary relationship between AtNPRl proteins with other NPR1 proteins from other plants species, a phylogenetic tree was produced. This was based on the alignment of presumed amino acid sequences of
AtNPRl and amino acid sequences involved in BLASTn results, using bootstrap consensus for neighbor joining, maximum parsimony and maximum likelihood. There are two main clusters in phylogenetic tree (Fig. 6) which was in agreement with reports by Zhao et al., (2009) and Henanff et al., (2009). AtNPRI was closely related non-expressor of PR1 from Arabidopsis lyrata subsp. Lyrata (XP_002886354) and regulatory protein NPR1 of Arabidopsis thaliana (NP_176610).

Nuclear localization of NPRI is mediated by a bipartite nuclear localization sequence at the carboxyl end of $N P R 1$, and is required for PR genes induction (Kinkema et al., 2000).There are two protein-protein interaction domains present, first a BTB/POZ domain (Aravind and Koonin, 1999) at the N-terminal end and second an Ankyrin-repeat domain (ARD) inthe center of the NPRI protein (Cao et al., 1997). Though, most of the proteins possess either ARD or BTB/POZ domains, NPRl has its place in an exclusive group of proteins that possess both domains. Ankyrin repeats domain and a BTB/POZ domain, found in some regulatory proteins and both of which mediate protein-protein interactions (Stogios et al., 2005; Cao et al., 1997; Ryals et al., 1997). Detailed studies on various nprl mutants known with amino acid changes in the consensus of these domains, have emphasized the functional importance of these protein-protein interaction domains (Cao et al., 1997; Ryals et al., 1997).

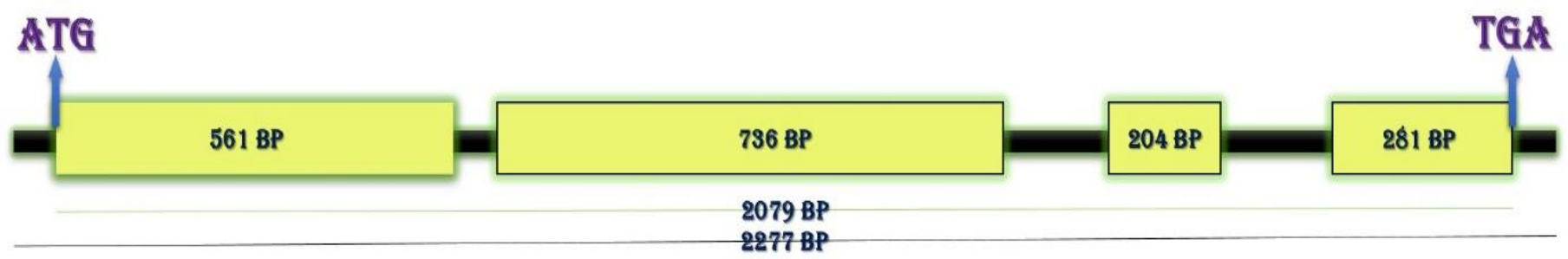

Fig. 4: AtNPRlgene assembly. Big rectangular boxes represent exons and thin black intervals represent introns. Size of the gene and size of exons are indicated.

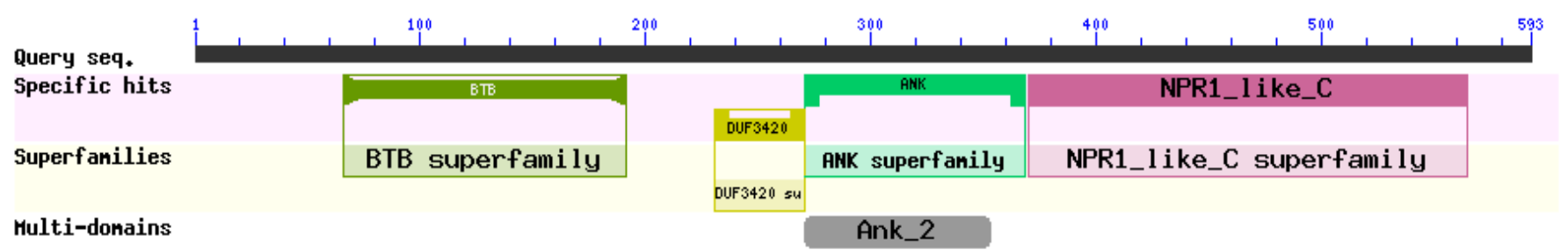

Fig. 5: The conserved domains analysis of the deduced AtNPR1 amino acid sequence using the NCBI CDD program. 


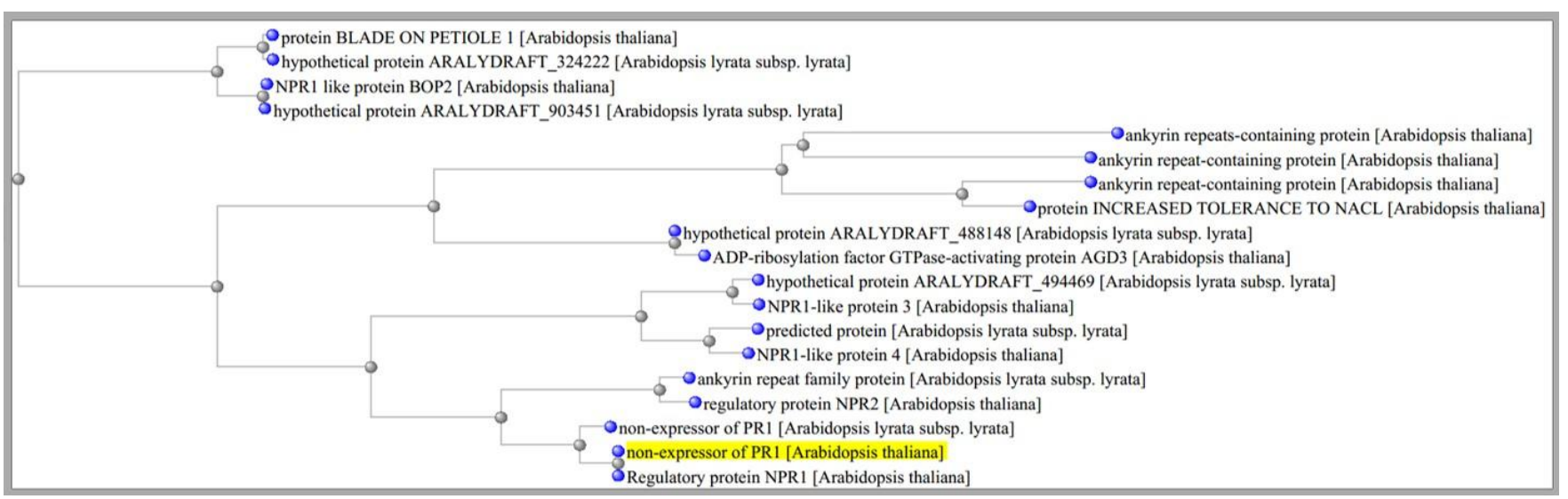

Fig. 6: A phylogenetic tree of AtNPRl with 18 other known Arabidopsis NPR1 proteins, made using online NCBI distance tree result domain in BLASTp.

In genetic engineering of economically important crops for improving resistance to spectrum of diseases, there is a vast potential use of SAR-related genes. We have chosen to clone this Arabidopsis NPRlgene, as its effectiveness in conferring an enhanced degree of non-specific disease resistance has been previously demonstrated in transgenic studies. In earlier studies, over expression of NPRI in plants have confer enhanced non-specific resistance plant pathogens, such as, enhanced resistance to an oomycete pathogen and a bacterial pathogen in Arabidopsis (Cao et al., 1998), resistance to bacterial blight in rice plants (Chern et al., 2001; Fitzgerald, 2004), enhanced resistance to Bacterial wilt (BW), Fusarium wilt (FW), Gray Leaf Spot (GLS) and Bacterial Spot (BS) in Tomato (Lin et al., 2004), resistance to Citrus canker, caused by Xanthomonas citri in Citrus plant (Zhang et al., 2010), enhanced resistance to Verticillium dahlia isolate TS2, Fusarium oxysporum f. sp. vasinfectum, Rhizoctonia solani, Alternaria alternata and Reniform Nematodes in cotton plant (Parkhi et al., 2010b) and resistance to root-knot nematode infection caused by Meloidogyne incognita in Tobacco (Priya et al., 2011).

For transgenic studies it is very much important to isolate and clone a full length functional gene. In our study, mRNA and amino acid sequence predicted, showed presence of full length functional protein which showed high homology towards the similar functional genes and proteins. Since, our ultimate goal is to explore the potential use of this AtNPRlgene for the genetic engineering of long lasting and broadrange disease-resistance, we have cloned and sequence characterized this gene in our lab for further studies. This AtNPRl gene is ready to use for genetic transformation of agricultural important crops.

\section{Conflict of interest statement}

Authors declare that they have no conflict of interest.

\section{Acknowledgement}

Authors wish to acknowledge with thanks to the Head, Department of Biotechnology, S.G.B. Amravati University, Amravati, Maharashtra, 444602, India for providing workbench and his constant encouragement.

\section{References}

Agrios, G.N., 2005. Plant Pathology. $5^{\text {th }}$ Edn. Academic Press, New York. 633p.

Aravind, L., Koonin, E.V., 1999. Fold prediction and evolutionary analysis of the POZ domain: Structural and evolutionary relationship with the potassium channel tetramerization domain. J. Mol. Biol. 285, 1353-1361.

Attaran, E., Zeier, T.E., Griebel, T., Zeier, J., 2009. Methyl salicylate production and jasmonate signaling are not essential for systemic acquired resistance in Arabidopsis. Plant Cell. 21(3), 954-971.

Cao, H., Bowling, S.A., Gordon, A.S., Dong, X., 1994. Characterization of an Arabidopsis mutant that is nonresponsive to inducers of systemic acquired resistance. Plant Cell. 6, 1583-1592.

Cao, H.., Li, X., Dong, X., 1998. Generation of broadspectrum disease resistance by over expression of an essential regulatory gene in systemic acquired resistance. Proc. Nat. Acad. Sci. USA. 95(11), 6531-6536.

Cao, H., Glazebrook, J., Clarke, J.D., Volko, S., Dong, X., 1997. The Arabidopsis NPR1 gene that controls systemic acquired resistance encodes a novel protein containing Ankyrin repeats. Cell. 88, 57-83.

CARE rating report, 2009. India loses Rs 90,000 cr crop yield to pest attacks each year. Article available at, http://www. livemint.com/Politics/eWIIt55ZCrSuuEPnwz7kKL/Indialoses-Rs90000-cr-crop-yield-to-pest-attacks-each-year.html. 
Chakrabarty, P.K., Chavhan, R.L., Ghosh, A, Gabriel, D.W., 2010. Rapid and efficient protocols for throughput extraction of high quality plasmid DNA from strains of Xanthomonas axonopodis pv malvacearum and Escherichia coli. J. Plant Biochem. Biotech. 19(1), 99102.

Chen, Y.Y., Lin, Y.M., Chao, T.C., Wang, J.F., Liu, A.C., Ho, F.I., Cheng, C.P., 2009. Virus induced gene silencing reveals the involvement of ethylene-, salicylic acid- and mitogen-activated protein kinase-related defense pathways in the resistance of tomato to bacterial wilt. Physiol. Plant. 136(3), 324-335.

Chern, M.S., Fitzgerald, H.A., Canlas, P.E., Navarre, D.A., Ronald, P.C., 2005. Over expression of a rice NPRI homolog leads to constitutive activation of defense response and hypersensitivity to light. Mol Plant Microbe Interact, 18, 511-520.

Chern, M.S., Fitzgerald, H.A., Yadav, R.C., Canlas, P.E., Dong, X, Ronald, P.C., 2001. Evidence for a diseaseresistance pathway in rice similar to the NPRI mediated signaling pathway in Arabidopsis. Plant J. 27, 101-113.

Clarke, J.D., Liu, Y, Klessig, D.F., Dong, X., 1998. Uncoupling PR gene expression from NPRI and bacterial resistance: characterization of the dominant Arabidopsis cpr6-1 mutant. Plant Cell. 10, 557-569.

Conrath, U., Pieterse, C.M., Mauch-Mani, B., 2002. Primingin plant-pathogen interactions. Trends Plant Sci. 7, 210-216.

Cui, Y., Bell, A.A., Joost, O., Magill, C., 2000. Expression of potential defense response genes in cotton. Physiol. Mol. Plant Pathol. 56, 25-31.

Delaney, T.P., Friedrich, L., Ryals, J.A., 1995. Arabidopsis signal transduction mutant defective in chemically and biologically induced disease resistance. Proc. Nat. Acad. Sci. USA. 92(14), 6602-6606.

Dhekney, S.A., Li, Z.T., Aman, M.A., Dutt, M., Tattersall, J., Gray, D.J., 2007. Genetic transformation of embryogenic cultures and recovery of transgenic plants in Vitis vinifera, Vitis rotundifolia and Vitis hybrids. Acta Hort. 738, 743-748.

Dong, X., 2004. NPR1, all things considered. Curr. Opin. Plant Biol. 7(5), 547-552.

Durrant, W.E., Dong, X., 2004. Systemic acquired resistance. Ann. Rev. Phytopathol. 42, 185-209.

Endah, R., Beyene, G., Kiggundu, A., van den Berg, N., Schlüter, U., Kunert, K., Chikwamba, R., 2008. Elicitor and Fusarium-induced expression of NPR1-like genes in banana. Plant Physiol. Biochem. 46, 1007-1014.

Feys, B.J., Parker, J.E., 2000. Interplay of signaling pathways in plant disease resistance. Trends Genet. 16(10), 449-455.

Fitzgerald, H.A., Chern, M.S., Navarre, R., Ronald, P.C., 2004. Overexpression of (At) NPR1in rice leads to a BTH- and environment-induced lesion-mimic/cell deathphenotype. Mol. Plant Microbe Interact. 17(2), 140151.

Gaffney, T., Friedrich, L., Vernooij, B., Negrotto, D., Nye, G., Uknes, S., Ward, E., Kessmann, H., Ryals, J., 1993. Requirement of salicylic acid for the induction of systemic acquired resistance. Sci. 261(5122), 754-756.
Glazebrook, J., Rogers, E.E., Ausubel, F.M., 1996. Isolation of Arabidopsis mutants with enhanced disease susceptibility by direct screening. Genetics. 143(2), 973-982.

Gotea, V., Veeramachaneni, V., Makałowski, W., 2003. Mastering seeds for genomic size nucleotide BLAST searches. Nucl. Acids Res. 31, 6935-6941.

Heath, M.C., 2000. Hypersensitive response-related death. Plant Mol. Biol. 44(3), 321-334.

Henanff, G.L., Heitz, T., Mestre, P., Mutterer, J., Walter, B., Chong, J.L., 2009. Characterization of Vitis vinifera NPRI homologs involved in the regulation of pathogenesis related gene expression. BMC Plant Biol. 9, 54.

Huang, L., Gill, B.S., 2001. An RGA-like marker detects all known Lr21 leaf rust resistance gene family members in Aegilops tauschii and wheat. Theor. Appl. Genet. 103, 1007-1013.

Jube, S., Borthakur, D., 2007. Expression of bacterial genes in transgenic tobacco: Methods, applications and future prospects. Electron. J. Biotechnol. 10, 452-467.

Kinkema, M., Fan, W., Dong, X., 2000. Nuclear localization of NPRl is required for activation of $\mathrm{PR}$ gene expression. Plant Cell. 12, 2339-2350.

Kohler, A., Schwindling, S., Conrath, U., 2002. Benzothiadiazole-induced priming for potentiated responses to pathogen infection, wounding, and infiltration of water into leaves requires the NPRI/NIMI gene in Arabidopsis. Plant Physiol. 128, 1046-1056.

Koornneef, A., Pieterse, C.M., 2008. Cross talk in defense signaling. Plant Physiol. 146(3), 839-844.

Kumar, V., Joshi, S.G., Bell, A.A., Rathore, K.S., 2012. Enhanced resistance against Thielaviopsis basicola in transgenic cotton plants expressing Arabidopsis NPRI gene. Transgenic Res. 22, 359-368.

Le, H.G., Heitz, T., Mestre, P., Mutterer, J., Walter, B., Chong, J., 2009. Characterization of Vitis vinifera NPRI homologs involved in the regulation of pathogenesisrelated gene expression. BMC Plant Biol. 9, 54.

Lee, H.I., Raikel, N.V., 1995. Prohevein is poorly processed but shows enhanced resistance to a chitin-binding fungus in transgenic tomato plants. Braz. J. Med. Biol. Res. 28, 743-750.

Leon-Reyes, A., Spoel, S.H., De-Lange, E.S., Abe, H., Kobayashi, M., Tsuda, S., Millenaar, F.F., Welschen, R.A., Ritsema, T., Pieterse, C.M., 2009. Ethylene modulates the role of nonexpressor of pathogenesisrelated genes1 in crosstalk between salicylate and jasmonate signaling. Plant Physiol. 149(4), 1797-1809.

Lin, W.C., Lu, C.F., Wu, J.W., Cheng, M.L., Lin, Y.M., Yang, N.S., Black, L, Green, S.K., Wang J.W., Cheng, C.P., 2004.Transgenic tomato plants expressing the Arabidopsis NPR1gene display enhanced resistance to a spectrum of fungal and bacterial diseases. Transgenic Res. 13, 567-581.

Liu, B., Zeng, Q., Yan, F.M., Xu, H.G., Xu, C.R., 2005. Effects of transgenic plants on soil microorganisms. Plant Soil. 271, 1-13.

Liu, Y., Schiff, M., Marathe, R., Dinesh-Kumar, S.P., 2002. Tobacco Rar1, EDS1 andNPR1/NIM1 like genes are 
required for $\mathrm{N}$-mediated resistance to tobacco mosaic virus. Plant J. 30(4), 415-429.

Loake, G., Grant, M., 2007. Salicylic acid in plant defense-the players and protagonists. Curr. Opin. Plant Biol. 10(5), 466-472.

Mace, E.S., Phong, D., Upadhyaya, H., Chandra, S., Crouch, J.H., 2006. SSR analysis of cultivated groundnut (Arachis hypogaea L.) germplasm resistant to rust and late leaf spot diseases. Euphytica. 152, 317-330.

Makandar, R., Essig, J.S., Schapaugh, M.A., Trick, H.N., Shah, J., 2006. Genetically engineered resistance to Fusarium head blight in wheat by expression of Arabidopsis NPR1. Mol. Plant Microbe Interact. 19(2), 123-129.

Malamy, J., Carr, J.P., Klessig, D.F., Raskin, I., 1990. Salicylic acid: a likely endogenous signal in the resistance response of tobacco to viral infection. Sci. 250, 1002-1004.

Malnoy, M., Jin, Q., Borejsza-Wysocka, E.E., He, S.Y., Aldwinchle, H.S., 2007. Overexpression of the apple MpNPR1gene confers increased disease resistance in Malus x domestica. Mol. Plant Microbe Interact. 20, 15681580.

Manczinger, L., Antal, Z., Kredics, L., 2002. Ecophysiology and breeding of mycoparasitic Trichoderma strains (a review). Acta Microbiol. Immunol. Hungarica. 49, 1-14.

Marchler-Bauer, A., Anderson, J.B., Cherukuri, P.F., DeWeese-Scott, C., 2005. CDD: a Conserved Domain Database for protein classification. Nucleic Acids Res. 33(Database issue): D192-D196.

Metraux, J.P., Signer, H., Ryals, J., Ward, E., Wyss-Benz, M., Gaudin, J., Raschdorf, K., Schmid, E., Blum, W., Inverardi, B., 1990. Increase in salicylic acid at the onset of systemic acquired resistance in cucumber. Sci. 250, 1004-1006.

Mou, Z., Fan, W., Dong, X., 2003. Inducers of plant systemic acquired resistance regulate NPR1 function through redox changes. Cell. 113(7), 935-944.

Mukhtar, M.S., Nishimura, M.T., Dang, J., 2009. NPR1 in plant defense: It's not over 'til It's turned over. Cell. 137(5), 804-806.

Mur, L.A., Kenton, P., Lloyd, A.J., Ougham, H., Prats, E., 2008. The hypersensitive response; the centenary is upon us but how much do we know? J. Exp. Bot. 59(3), 501520.

Ndamukong, I., Abdallat, A.A., Thurow, C., Fode, B., Zander, M., Weigel, R., Gatz, C., 2007. SA-inducible Arabidopsis glutaredoxin interacts with TGA factors and suppresses JA-responsive PDF1.2 transcription. Plant J. 50(1), 128139.

Parkhi, V., Kumar, V., Campbell, L.M., Bell, A.A., Rathore, K.S., 2010b. Expression of Arabidopsis NPRI in transgenic cotton confers resistance to non-defoliating isolates of Verticillium dahliae but not the defoliating isolates. J. Phytopathol. 58(11-12), 822-825.

Parkhi, V., Kumar, V., Campbell, L.M., Bell, A.A., Shah, J, Rathore, K.S., 2010a. Resistance against various fungal pathogens and reniform nematode in transgenic cotton plants expressing Arabidopsis NPR1. Transgenic Res. 19(6), 959-75.

Pilotti, M., Brunetti, A., Gallelli, A., Loreti, S., 2008. NPR1like genes from cDNA of rosaceous trees: cloning strategy and genetic variation. Tree Genet. Genomes. 4, 49-63.

Priya, D.B., Somasekhar, N., Prasad, J.S., Kirti, P.B., 2011. Transgenic tobacco plants constitutively expressing Arabidopsis NPRl show enhanced resistance to root-knot nematode, Meloidogyne incognita. BMC Res. Notes. 4, 231.

Rangaswami, G., Mahadevan, A., 2005. Diseases of cash crops, Diseases of crop plants in India, $4^{\text {th }}$ edition published by Prentince-Hall of Ind. Pvt. Ltd. New Delhi. $425 \mathrm{p}$.

Rasmussen, J.B., Hammerschmidt, R., Zook, M.N., 1991. Systemic induction of salicylic acid accumulation in cucumber after inoculation with Pseudomonas syringae pv. syringae. Plant Physiol. 97, 1342-1347.

Rochon, A., Boyle, P., Wignes, T., Fobert, P.R., Despres, C., 2006. The coactivator function of Arabidopsis NPR1 requires the core of its $\mathrm{BTB} / \mathrm{POZ}$ domain and the oxidation of C-terminal cysteines. Plant Cell. 18(12), 3670-3685.

Rommens, C.M., Kishore, G.M., 2000. Exploiting the full potential of disease-resistance genes for agricultural use. Curr. Opin. Biotechnol. 11, 120-125.

Ryals, J., Weymann, K., Lawton, K., Friedrich, L., Ellis, D., Steiner, H,Y., Johnson, J., Delaney, T.P., Jesse, T., Vos, P., 1997. The Arabidopsis NIM1 protein shows homology to the mammalian transcription factor inhibitor I kappa B. Plant Cell. 9(3), 425-439.

Ryals, J.A., Neuenschwander, U.H., Willits, M.G., Molina, A, Steiner, H.Y., Hunt, M.D., 1996. Systemic acquired resistance. Plant Cell. 8, 1809-1819.

Salmeron, J. M., Vernooij, B., 1998. Transgenic approaches to microbial disease resistance in crop plants. Curr. Opin. Plant Biol. 1, 347-352.

Sanghera, G. S., Gill, M. S., Gosal, S. S., Wani, S.H., 2009. RNA Interference: Its Concept and application in crop plants. In: Biotechnology: Cracking New Pastures. Malik C. P. MD Publications, New Delhi, India. pp.33-78.

Sarah, J. G., Paul, J. R., 2005. Engineering plants with increased disease resistance: what are we doing to express? Trends Biotechnol. 23(6), 275-282.

Shah, J., Tsui, F., Klessig, D.F., 1997. Characterization of a salicylic acid-insensitive mutant (sai1) of Arabidopsis thaliana, identified in a selective screen utilizing the SAinducible expression of the tms 2 gene. Mol. Plant Microbe Interact. 10, 69-78.

Smith, J.D., 2002. Assessment of spring wheat accessions for disease reaction to Rhizoctonia solani AG-8 in controlled environment and direct seeded field evaluations. Crop Sci. 43, 694-700.

Spoel, S.H., Koornneef, A., Claessens, S.M., Korzelius, J.P., Van-Pelt, J.A., Mueller, M.J., Buchala, A.J., Metraux, J.P., Brown, R., Kazan, K., 2003. NPR1 modulates crosstalk between salicylate- and jasmonate-dependent defense 
pathways through a novel function in the cytosol. Plant Cell, 15(3), 760-770.

Stogios, P.J., Downs, G.S., Jauhal, J.J., Nandra, S.K., Prive, G.G. 2005. Sequence and structural analysis of BTB domain proteins. Genome Biol. 6(10), R82.

Stuiver, M.H., Custers, J.H., 2001. Engineering disease resistance in plants. Nat. 411, 865-868.

Vlot, A.C., Klessig, D.F., Park, S.W., 2008. Systemic acquired resistance: the elusive signal(s). Curr. Opin. Plant Biol, 11(4), 436-442.

Wani, S.H., 2010. Inducing fungus-resistance into plants through biotechnology. Not Sci. Biol, 2(2), 14-21.

Wani, S.H., Sanghera, G.S., 2010. Genetic engineering for viral disease management in plants. Not Sci. Biol. 2(1), 20-28.

Ward, E.R., Uknes, S.J., Williams, S.C., Dincher, S.S., Wiederhold, D.L., Alexander, D.C., Ahl-Goy, P, Metraux, J.P., Ryals, J.A., 1991. Coordinate gene activity in response to agents that induce systemic acquired resistance. Plant Cell. 3, 1085-1094.

Yu, D., Chen, C., Chen, Z., 2001. Evidence for an important role of WRKY DNA binding proteins in the regulation of NPR1 gene expression. Plant Cell. 13(7), 1527-1540.
Yuan, Y., Zhong, S., Li, Q., Zhu, Z., Lou, Y., Wang, L., Wang, J.., Wang, M., Yang, D., He, Z., 2007. Functional analysis of rice NPR1-like genes reveals that OsNPR1/NH1 is the rice orthologue conferring disease resistance with enhanced herbivore susceptibility. Plant Biotechnol. J. 5(2), 313-324.

Zhang, X., Marta, F., William, O.D., Graham, J.H., Orbovic, V., Triplett, E.W., Mou, Z., 2010. Over-expression of the Arabidopsis NPR1 gene in citrus increases resistance to citrus canker. Eur. J. Plant Pathol. 128(1), 91-100.

Zhang, Y., Wang, X., Cheng, C., Gao, Q., Liu, J., Guo, X., 2008. Molecular cloning and characterization of GhNPRl, a gene implicated in pathogen responses from cotton (Gossypium hirsutum L.). Biosci. Rep. 28, 7-14.

Zhao, J.T., Huang, X, Chen, Y.P.,Chen, Y.E., Huang, X.L., 2009. Molecular cloning and characterization of an ortholog of NPR1 Gene from Dongguan Dajiao (Musa spp. ABB). Plant Mol. Biol. Rep. 27, 243-249.

\section{How to cite this article:}

Kalbande, B. B., Patil, A. S., 2016. Cloning and characterization of NPR1 gene from Arabidopsis thaliana ecotype Col-0. Int. J. Curr. Res. Biosci. Plant Biol. 3(2), 15-26.

doi: $\underline{\text { http://dx.doi.org/10.20546/ijcrbp.2016.302.003 }}$ 